\title{
Student response of Medan State University to independent campus discussion
}

\author{
Indah Wahyuni ${ }^{\mathrm{a}, 1, *}$, Akhyar Anshori ${ }^{\mathrm{b}, 2}$ \\ ${ }^{\text {a } U n i v e r s i t y ~ o f ~ M u h a m m a d i y a h ~ S u m a t e r a ~ U t a r a ~}$ \\ ${ }^{1}$ indahwahyuni2198@gmail.com*; ${ }^{2}$ akhyaransori@umsu.ac.id \\ * corresponding author
}

Article history

Received 06-01-2021

Revised 18-01-2021

Accepted 02-02-2021

Keywords

Student Response

Unimed

Discourse

Independent Campus

\begin{abstract}
Some time ago, Minister of Education and Culture (Mendikbud) Nadiem Makarim launched a program called "Merdeka Learning" aimed at Universities / Colleges which is also known as the Independent Campus. The discourse conveyed by the Minister of Education and Culture regarding the Merdeka Campus has four policies in the scope of higher education, namely (1) Opening of new study programs, in which this program provides autonomy for State (PTN) and Private Universities (PTS) to open or establish new study programs, (2) Higher education accreditation system, (3) Freedom for PTN Public Service Agency (BLU) and Work Unit (Satker) to become PTN Legal Entity (PTN BH), (4) Right for students to take courses outside the study program and changing the definition of the Semester Credit System (SKS). The purpose of this study was to determine how the Medan State University Student Response to the Discourse of the Merdeka Campus. The data collection technique used in this study used several methods including literature study, observation, interviews, and documentation. This data analysis technique uses a qualitative descriptive method which is used to describe a situation that is currently running at the time the research is carried out and examines the causes of a particular symptom, then analyzed by conducting a conceptual examination of a statement so that the clarity of the meaning contained in the statement can be obtained. the. Where all the speakers know the discourse on an independent campus that has been conveyed by the Minister of Education and Culture some time ago, but from the results of the interviews conducted in more depth, five people only approved and three people did not approve of the independent campus.
\end{abstract}

This is an open access article under the CC-BY-SA license.

\section{Introduction}

To increase the nation's competitiveness in the face of globalization in all fields, higher education is needed that is capable of developing science and technology that can produce cultured and creative intellectuals (professionals), tolerant, democratic, strong character and courageous to defend the truth for the benefit of the nation. Higher education institutions are required to be able to 
design and implement innovative learning processes so that students can achieve optimal and relevant learning outcomes through aspects of attitude, knowledge, and skills (Paramitha, 2020).

On January 24, 2020, Minister of Education and Culture (Mendikbud) Nadiem Makarim launched a program called "Merdeka Learning" aimed at Universities / Colleges which is also called "Independent Campus". The discourse conveyed by the Minister of Education and Culture regarding the Merdeka Campus has four policies in the scope of higher education, namely (1) Opening of new study programs, in which this program provides autonomy for State (PTN) and Private Universities (PTS) to open or establish new study programs, (2) Higher education accreditation system, (3) Freedom for PTN Public Service Agency (BLU) and Work Unit (Satker) to become PTN Legal Entity (PTN BH), (4) Right for students to take courses outside the study program and changing the definition of the Semester Credit System (SKS) (Zhao, Chen, \& Zhao, 2020).

Nadiem said that the implementation of the Free Campus would be held soon, this would only change the Ministerial Regulation and not change the Government Regulation or the Constitution. Where an independent campus is a form of learning in an autonomous and flexible university to create a learning culture that is innovative, non-restrictive and following the needs of students (Lotan, 2019).

At a higher level, namely education at universities/colleges as described in Law No.12 of 2012 concerning Higher Education, where higher education is part of the national education system which has a strategic role in educating the nation's life, advancing science and technology. by paying attention to at the same time applying the values of humanities, civilizing and sustainably empowering the Indonesian nation (Putra \& Smolek, 2020).

Based on the description of the background, the authors are interested in conducting further research to find new aspects related to student responses to policies in the title of the thesis "Student Responses at Medan State University Against Discourse on Merdeka Campus". The purpose of this study is to see an overview of the response of Medan State University students to the discourse of an independent campus (Jandevi, 2019).

\section{Theorotocal Framework}

a) Communication

Communication (Ramli, 2013) is a series of actions or events that occur sequentially (there are stages) and are related to each other within a certain period. If communication is viewed from a broad sense not only as an exchange of news and messages but as an individual and group activity regarding the exchange of data, facts, and ideas, then its function in each social system is as follows:

- Information, collection, storage, processing, dissemination of news, data, pictures, facts, messages, opinions, and comments need to be understood and act clearly on environmental conditions and other people to make the right decisions.

- Socialization (correctional), the provision of a source of knowledge that allows people to behave and act as effective members of society so that they are aware of their social functions and can be active in society (Luhuringbudi, Syamsuddin, \& Hakim, 2019).

- Motivation, explaining the short-term and long-term goals of each society, encourages people to determine their preferences and desires, encourages individual and group activities based on common goals to be pursued (Fadillah, 2014).

- Debates and discussions, providing and exchanging facts necessary to allow agreement or resolution of disagreements on public matters, providing relevant evidence needed for the public interest so that the public is more involved with issues of mutual interest (Sintawati, 2019).

- Education, the transfer of knowledge can encourage intellectual development, shape character, and shape the skills and skills needed in all areas of life. 
- Advancing life, spreading cultural and artistic products to preserve the past, developing culture by expanding one's horizons and building imagination, and encouraging creativity and aesthetic needs (Fadillah, 2020).

- Entertainment, the dissemination of signals, symbols, sounds, and imaginations from drama, dance, art, literature, music, sports, group, and individual fun.

- Integration provides for nations, groups, and individuals the opportunity to get the various messages they need so that they can know each other and understand and respect the conditions of the views and desires of others (Widjaja, 2010).

\section{b) Definition of Response}

In the Complete Dictionary of Psychology, it is stated that the response is any muscle or glandular process that is generated by a stimulant or means an answer, especially the answer to a text question or a questionnaire or it can also be any behavior, whether it is obvious or visible or external. hidden or cryptic (Chaplin, 2018). The response will only exist if it is in the form of verbal behavior and behavioral deeds, then actions that determine whether to accept or reject the stimuli are given (Harahap, Jayanegara, Nahrowi, \& Fakhri, 2018). Responses can be classified into three categories, namely:

\section{- Knowledge Area (Cognitive Response)}

Is the result of a person's perception and knowledge of an object where this cognitive component arises with a change in what is understood by the public, this response is also related to a person's knowledge of information about a matter.

- Feeling Area (Affective Response)

Describes feelings and emotional reactions as a result of evaluating objects where this effective component is related to a person's emotions, souls, attitudes, and feelings towards something. This response arises when there is a change in what the audience likes about something.

- Area of Action (Conative Response)

This response is related to real behavior which includes actions or habits of behavior, showing a tendency to act in a certain way towards certain objects (Bondzi-Simpson \& Ayeh, 2017).

c) College student

According to the Big Indonesian Dictionary, a student is someone who studies at a university. Within the educational structure in Indonesia, students hold the highest educational status among the others (KBBI). A student is someone who is in the process of gaining knowledge or studying and is registered while undergoing education at one form of higher education which consists of academics, polytechnics, high schools, institutes, and universities (Gautama \& Hartaji, 2004).

d) Discourse on an Independent Campus

In KBBI (Big Indonesian Dictionary), there are three meanings of the word discourse. One is conversation, speech, and speech. The second meaning is the total number of speech or words which means unity, while the third meaning is the largest language unity, the realization is complete and has a very intact composition such as fiction, novels, and books. Discourse is also defined as an ability that is used to discuss current topics in an orderly and proper order (Judge, 2020).

Based on the direction of the Minister of Education and Culture Nadiem Makarim which is contained in the Free Learning Campus Guidebook issued to the Ministry of Education and Culture (Ministry \& Education, 2004), to prepare students and female students who will face changes in the social, cultural world of work and technology which is very rapid as it is currently forcing students to prepare themselves according to the needs of the times.

Educational institutions such as universities must be required to design and implement innovative learning that aims to achieve learning outcomes including several aspects such as optimal attitudes, knowledge, and skills. The policy made by the government regarding Free Learning is also expected to be an answer to the demands of today's developments because independent campuses 
are a tangible manifestation of learning in universities that are autonomous and flexible so that later they can create a learning culture that is innovative, non-restrictive and according to needs.

\section{Method}

This research is included in the type of qualitative research, where the specification of this research is descriptive qualitative, this is considered appropriate because qualitative data can follow and understand the flow of events chronologically (Sugiyono, 2016), descriptive qualitative research is research that seeks to describe the current problem solving based on data, to analyze and to interpret. The informants in this study were students of Medan State University, Faculty of Education, 2017 Outdoor Education Study Program who knew the discourse of an independent campus.

\section{Results and Discussion}

The response is a reaction or response (perception) of individuals or groups to something that catches their attention. So that the impression appears that they are observing something, which later each individual will provide a response or meaning to events that occur in their environment. The process of forming this response starts from the emergence of behavior that can determine whether the response is accepted or rejected from a given stimulus where later there will be a response in the form of verbal behavior or deed behavior (Leibo \& Poggio, 2018).

As for the response of Medan State University students to the discourse on an independent campus, which has been designated as a resource and eventually various responses or reactions expressed by the resource person themselves emerged. The responses experienced by these students are of course different for each individual, this is because the stimulus of each individual can be different as well as this stimulus is an important factor that shapes the response of each individual.

Student responses arise when interviewed by researchers, so researchers know how the responses given by the eight students are used as sources. All informants were aware of the discourse on an independent campus that was conveyed by the Minister of Education and Culture some time ago, but from the results of the interviews conducted in more depth, five people only approved, and three people did not approve of the independent campus (Fajri, 2020).

It can be said that the five people who agree are categorized into cognitive responses or the socalled knowledge area, where this response shows the results of a person's perception and knowledge of an object or is related to someone's knowledge of information about something, based on their knowledge, the five sources who know about campus independence is of course very much in agreement with the independent campus policy conveyed by the minister of education some time ago.

Meanwhile, the three speakers who did not agree with the existence of an independent campus could be categorized into affective responses or feeling areas, where the informant also explained that feelings and emotions arise as a result of an object of something and the response that arises occurs when there is a change in something that is happening. the public likes something.

Students as academic persons who seek and study in both private and public tertiary institutions must be able and have reasoning and understanding, intelligence when thinking, and being able to plan in determining attitudes quickly, directed, and precisely are traits that tend to be owned and attached to students. Medan State University is a public university located in North Sumatra, where this college was founded to improve the quality of the implementation of the Educational Personnel Education Institute (LPTK). With the presence of the unimed students as accurate sources, it is easy to analyze public opinion through the responses given by students regarding the discourse on an independent campus which was conveyed by the Education Minister some time ago

However, of the eight resource persons, there are only five people who know all the contents of the points contained in the independent campus and the other three only know one point from the independent campus where that point is the freedom to study outside the study program, this is due to the limited information being socialized by related parties. 
Discourse is the whole picture of a conversation that has the definition of a unified whole in an orderly and proper discussion topic. The view of linguistics in the analysis of discourse is first that the analysis of discourse has the intention of describing the linguistic structure of the meaning solely by using syntax and semantics as a consideration whether it is considered true or not. The second view is constructivism which means rejecting positivism which can separate a subject and object in language. This view states that language can also be regulated and can generate statements that have a purpose because every statement is essentially the creation of meaning, an attitude of selfformation, and what is expressed happens from the speaker or writer.

The third is a critical view. The point is where this view can correct the constructivism view. This view emphasizes that discourse must be able to give strength to a process of production and reproduction of meaning, someone is not a neutral subject who can provide a free interpretation according to what he thinks because of the influence of social forces.

Permendikbud regarding the discourse of independent learning - an independent campus to prepare students to face social, cultural, a world of work and rapid technological advances, student competencies must be prepared to move forward more with the needs of the times. All of these activities must be carried out with guidance from lecturers, an independent campus is expected to provide contextual field experiences that will improve student competence as a whole, be ready to work, or create new jobs.

However, based on student responses in response to the readiness of higher education institutions to run this independent campus program, of course, it is not completely ready if Indonesian universities will implement this latest breakthrough, this program needs to be studied more deeply what the positive and negative impacts are because Indonesia has various universities and different cultures must be thoroughly socialized and adapted for this program to run well.

Moreover, regarding the points of opening a new study program on this independent campus, several speakers either agreed or did not regarding this matter. Resource persons 1 (one), 2 (two), 3 (three), 4 (four), 6 (six), 7 (seven) assume that the health and education study program must have a fixed concentration because both are absolute sciences by therefore it is the right decision to make.

Meanwhile, resource persons 5 (five) and resource persons 8 (eight) responded that the point was not correct, all study programs should be able to implement the policy without any exceptions then should be free to learn - this independent campus is an arena of freedom in the world of higher education. This made the informants object to the existence of exceptions aimed at health and education study programs.

In the point of the higher education accreditation system according to the one resource person, the system can be a benchmark in terms of higher education quality because in a university it is likened to a system that has various elements such as teaching staff, facilities, and infrastructure, student graduates and their achievements. Therefore, this would not be possible if accreditation was obtained only voluntarily, which is feared this could endanger the quality of higher education in the future. Likewise, according to resource 2 (two), resource 3 (three), resource 4 (four), resource 5 (five), resource person 6 (six), resource 7 (seven) and resource person 8 (eight) stated that of course, this is also true. It influences or can be a benchmark in terms of quality in each university because as we all know that campus accreditation is one of the qualities of a campus.

Meanwhile, he also emphasized that this is also a factor when a prospective student chooses the faculty and department he wants, of course, the first thing that is seen is his accreditation. Regarding the point that PTN - BLU can apply to become PTN - BH, most of the informants do not know this, only 1 (one) informant knows this, where he said that the status of Medan State University is as PTN - BLU, while other informants do not know it. due to a lack of information or socialization carried out to related parties to students and universities so that this should be considered again. Meanwhile, the program takes courses outside the study program or other campuses that the 1 (one) resource person wants is student exchange, if the opportunity is within the right to study three semesters outside the study program, the resource person 3 (three) wants to take the opportunity to study in English literature too because he like it at the same time can add insight. Resource persons 4 (four) want a village building program / KKNT, which later aims to develop competencies and use digital technology for community learning, resource people 5 (five) have the opportunity to take courses 
outside the study program, then they will choose an apprenticeship program or work practice because According to him, this can convey the knowledge obtained to the community, resource persons 6 (six) want entrepreneurial activities, especially governance because the informants want to be more skilled to have that ability. Meanwhile, resource 2 (two) and resource person 7 (seven) are still confused about which program and what program he wants if the discourse on an independent campus runs because he has not thought about it, and resource person 8 (eight) states that it is not right to be implemented. at University. This happened due to the lack of socialization and the students' curiosity about learning independently - the independent campus, said the Minister of Education and Culture some time ago.

\section{Conclusion}

Medan State University students are aware of the discourse of Merdeka Learning. However, some students disagree with as many as 3 people for independent learning - an independent campus, and some students agree with as many as 5 people. Merdeka Belajar - an independent campus is based on the responses of the informants that this must be considered carefully if it is to be applied in higher education because of the importance of this study for the program to run smoothly. Lack of information provided or socialized by related parties and students' curiosity about this, so that most of the speakers did not know all the points contained in the discourse on the independent campus.

\section{Acknowledgment}

The author would like to express his deep gratitude to the Communication Studies Program at the Muhammadiyah University of North Sumatra, which has been the author's tool when he was a student of the Faculty of Social and Political Sciences, Muhammadiyah University of North Sumatra.

\section{References}

Bondzi-Simpson, A., \& Ayeh, J. K. (2017). Serving indigenous dishes in hotels: An inquiry into the conative response of menu decision makers. International Journal of Hospitality Management. https://doi.org/10.1016/j.ijhm.2017.08.010

Chaplin, S. (2018). Attention deficit hyperactivity disorder: Diagnosis and management. Progress in Neurology and Psychiatry. https://doi.org/10.1002/pnp.511

Fadillah, D. (2014). Strategi komunikasi pembentukan budaya organisasi. Humanika, 14(1). https://doi.org/https://doi.org/10.21831/hum.v14i1.3327

Fadillah, D. (2020). HYPER REALITAS SIMULAKRA TAGAR \#2019GANTIPRESIDEN DALAM PEMILIHAN PRESIDEN INDONESIA 2019. Profetik: Jurnal Komunikasi, 12(2), 249. https://doi.org/10.14421/pjk.v12i2.1669

Fajri, C. (2020). Teacher's emphatic communication to improve learning motivation of special needs students. International Journal of Communication and Society, 2(1), 41-46. https://doi.org/10.31763/ijcs.v2i1.77

Gautama, R. S., \& Hartaji, S. (2004). Improving the accuracy of geochemical rock modelling for acid rock drainage prevention in coal mine. Mine Water and the Environment. https://doi.org/10.1007/s10230-0040047-x

Harahap, R. P., Jayanegara, A., Nahrowi, \& Fakhri, S. (2018). Evaluation of oil palm fronds using fiber cracking technology combined with Indigofera $\mathrm{sp}$. in ruminant ration by Rusitec. AIP Conference Proceedings. https://doi.org/10.1063/1.5062758

Jandevi, U. (2019). Communication strategy to improve women's political participation in Indonesia. International Journal of Communication and Society, 1(2), 68-81. https://doi.org/10.31763/ijcs.v1i2.46

Judge, P. (2020). Under pressure. New Scientist. https://doi.org/10.1016/S0262-4079(20)30936-2 
Leibo, J. Z., \& Poggio, T. (2018). Perception. In Living Machines: A Handbook of Research in Biomimetic and Biohybrid Systems. https://doi.org/10.1093/oso/9780199674923.003.0025

Lotan, F. F. (2019). Making a positive internet through Socmed Agawe Guyub. International Journal of Communication and Society, 1(1), 9-16. https://doi.org/10.31763/ijcs.v1i1.22

Luhuringbudi, T., Syamsuddin, M. D., \& Hakim, S. A. (2019). Activists communication dynamics for mobilization of minority politics in europe. International Journal of Communication and Society, 1(2), 4357. https://doi.org/10.31763/ijcs.v1i2.50

Ministry, T., \& Education, A. (2004). Ministry of advanced education. Comparative and General Pharmacology.

Paramitha, A. (2020). Komunikasi efektif komunitas rumah baca dalam meningkatkan minat baca pada anakanak di dusun Kanoman. COMMICAST, 1(1), 1. https://doi.org/10.12928/commicast.v1i1.2408

Putra, F. D., \& Smolek, S. (2020). Peace language and conflict resolution in harmony communication. International Journal of Communication and Society, 2(2), 86-93. https://doi.org/10.31763/ijcs.v2i2.134

Ramli, R. (2013). Culturally appropriate communication in Malaysia: budi bahasa as warranty component in Malaysian discourse. Journal of Multicultural Discourses. https://doi.org/10.1080/17447143.2012.753895

Sintawati, W. (2019). Computer mediated communication for construction-supported constructivism in communication and cultural learning. International Journal of Communication and Society, 1(1), 34-42. https://doi.org/http://dx.doi.org/10.31763/ijcs.v1i1.29

Sugiyono, P. D. metode penelitian kuantitatif, kualitatif,dan R\&D. , Alfabeta, cv. (2016).

Widjaja, E. (2010). Motivation Behind Volunteerism. CMC Senior Theses.

Zhao, J., Chen, C., \& Zhao, L. (2020). The spread characteristics of music videos relating to COVID-19 in China online video platforms. International Journal of Communication and Society, 2(1), 1-11. https://doi.org/10.31763/ijcs.v2i1.94 